\title{
Seismites in the Pleistocene succession and recurrence period of large earthquakes in the Kathmandu Valley, Nepal
}

\author{
T. Sakai ${ }^{* *}$, A. P. Gajurel ${ }^{2}$ and H. Tabata ${ }^{3}$
}

\begin{abstract}
Background: Kathmandu Valley, which is a rapidly growing place in Nepal, was largely damaged by the earthquakes of April 25 (Mw 7.8) and May 12 (Mw 7.3). For taking measures against future large earthquakes, knowledge of the long-term earthquake history is crucial for future disaster prevention or disaster reduction.

Results: Twelve seismites thicker than $0.2 \mathrm{~m}$ were identified from the Tokha Formation, the major part of which was deposited at about 20 - $17 \mathrm{ka}$ (calibrated ${ }^{14} \mathrm{C}$ ages). Some seismites show evidence of sliding occurred on the delta plain.

Conclusions: The reconstructed earthquake recurrence period is ca. 0.25 ka or shorter. Six of the seismites show evidence of sliding when deformation structures were formed. This was probably due to the tilting of the surface in the studied site, where a buried flexure was discovered nearby. The discovery of the seismites with sliding in the delta plain deposit suggests the possibility of sliding by future large earthquakes and requirement of risk management for the plain area of the Kathmandu Valley.
\end{abstract}

Keywords: Seismite, Kathmandu valley, Tokha formation, Pleistocene, Recurrence of earthquake

\section{Background}

The aim of this study is to describe sediments associated with earthquake tremor recorded within the sediment succession in the eastern Kathmandu Valley, central Nepal, and to estimate the recurrence time period of large earthquakes. The intensity and recurrence period of paleoearthquakes are generally estimated from the study of geomorphic features such as terraces formed by the uplift and analyses of active faults in trenches (e.g. Nakata, 1989; Wesnousky et al., 1999; Malik and Mathew, 2005; Malik et al., 2010). These methods are not suitable for rapidly subsiding basins, because most geologic and geomorphic records left by earthquakes may have been subsequently buried by sediments or masked by inundations during rapid flooding of lake or sea water. Instead, the analyses of sedimentary successions, particularly soft-sediment deformation structures (SSDs), can be a strong tool for detecting the evidence of past earthquakes (e.g. Seilacher, 1969, 1984; Agnon

\footnotetext{
* Correspondence: sake@riko.shimane-u.ac.jp

'Department of Geoscience, Shimane University, Matsue 690-8504, Japan Full list of author information is available at the end of the article
}

et al., 2006; Simms, 2007; Rossetti et al., 2011) and estimating the recurrence time of major earthquakes (e.g. Sims, 1973, 1975). Turbidites and debrites have also been used to estimate earthquake recurrence periods in marine and lake basins (Kastens, 1984; Ikehara, 2000).

Within the Himalayan Range, knowing the history of paleoearthquakes is crucial in terms of disaster prevention. In particular, expanding cities in intermontane basins in the Himalayas, such as in the Kathmandu and Pokhara valleys, have been facing the problem of a possibility of the occurrence of large earthquakes. The recent rapid increase in population and expansion of urban areas, particularly within the Kathmandu Valley, resulted in large damages by $\mathrm{Mw} 7.8$ and $\mathrm{Mw} 7.3$ earthquakes occurred in April 25 and May 12, 2015, in central and eastern Nepal, respectively. If earthquakes with large magnitude like 1505's earthquake (cf. Ambraseys and Douglas, 2004) occurred around Kathmandu, the damage could be significantly greater than that for the recent earthquake events. Taking precautions against next large earthquakes is an urgent task for Kathmandu Valley.

\section{勿 Springer}


SSDs associated with earthquakes are called seismites. Seismites in the Pleistocene succession of the Kathmandu Valley have been reported by several researchers (Gajurel et al., 1998; Gajurel, 2006, Mugnier et al., 2011). Gajurel et al. (1998) provided an excellent description of thick beds with SSDs, interpreted them as seismites, and inferred the earthquake intensity on the basis of the empirical relationship between seismite thickness and earthquake intensity on the MMI scale (Hibsch et al., 1997). Mugnier et al. (2011) also showed evidence for mega-earthquakes based on seismites and compiled the history of earthquakes that affected the Kathmandu Valley after $1000 \mathrm{AD}$ as well as some prehistoric earthquakes. These studies demonstrated the occurrence of earthquakes probably stronger than $\mathrm{X}$ on the MMI scale in the past.

Establishment of the long-term history of earthquakes within and around basins is crucial in order to detect the recurrence period of such large earthquakes, which assists with precautionary measures against future earthquake disasters. Kathmandu Valley, the target of this study, is a suitable place for the analysis of long-term earthquake history, because a thick basin-fill sediment succession formed between 10 and $50 \mathrm{ka}$ is exposed on land, allowing easy access to the long-term sedimentary record.

\section{Stratigraphy, chronology, and tectonics of the Kathmandu Valley Stratigraphy and chronology}

The Kathmandu Valley (Fig. 1a) is an intermontane basin developed within the Kathmandu nappe (e.g., Stöcklin and Bhattarai, 1977) and has been recognized as a piggyback basin (Sakai, 2001) (Fig. 1b). The basin fill has been estimated to be more than $600 \mathrm{~m}$ (Moribayashi and Maruo, 1980) and is dated from the early Pleistocene (Sakai, 2001). The exposed part of the Pleistocene succession consists of the Gokarna (ca. 50-34 ka: based on uncalibrated ${ }^{14} \mathrm{C}$ ages), Thimi (33-24 ka), Tokha (19-14 ka), and Patan formations (14-10 ka) from the oldest to youngest (Sakai et al., 2008) (Fig. 2). Black mud beds, defined as the Kalimati Formation (Kalimati means "black mud" in the Nepali), are widely distributed in the central part of the basin (Shrestha et al., 1998; Sakai 2001; Dill et al., 2001) and may interfinger with all the other formations (Sakai et al., 2008).

The sediments of the Gokarna, Thimi, Tokha, and Patan formations show lithological similarities with each other. Alternating sand and silt beds of lacustrine deltaic origin characterize the major part of these formations, while the gravel-dominated sediments of alluvial fan or subaqueous slope origin are observed in the proximal parts of the Gokarna and Tokha formations (Natori et al. 1980; Yoshida and Igarashi, 1984; Sakai et al., 2001,
2006, 2008; Saijo and Kimura, 2007; Tamrakar et al., 2009). The sediments of all formations are horizontal except those near the basin margin, where slope facies has been observed (Sakai et al., 2008). The sediments form a series of depositional terraces in the central and northern part of the basin. The Gokarna and Tokha formations form the Gokarna Terrace. The Thimi and Patan formations constitute the Thimi and Patan terraces, respectively (Fig. 1a).

In terms of the sedimentation of these formations and building of these terraces, Yoshida and Igarashi (1984) interpreted that deposition first occurred in the higher level of the basin ("Gokarna Formation" of their definition), and subsequently shifted down to the lower level of the basin (Thimi to Patan formations). The sedimentary sequence was recognized as having been associated with the long-term lowering of the lake level. Sakai et al. (2008) redefined the upper part of the above mentioned "Gokarna Formation" as the Tokha Formation based on abundant ${ }^{14} \mathrm{C}$ age data and the discovery of an unconformity within the previous "Gokarna Formation," suggesting that the lake level rose after the deposition of the Thimi Formation. Sakai et al. (2006) also discovered sediments demonstrating a rapid lake-level fall during the deposition of the Gokarna Formation at around $39 \mathrm{ka}$ (Sakai et al., 2008). The reconstructed lake-level curve (Sakai and Gajurel, 2012) indicates several occurrences at different times of rapid lake-level fall events, probably caused by the destruction of the plug at the gorge of the basin outlet (Sakai et al., 2006, Gajurel, 2011). Therefore, lake formation within the Kathmandu Valley was interpreted as having been due to the plugging of the basin by a large-scale landslide at the gorge of the basin outlet. The Upper Pleistocene succession of the Kathmandu Valley can therefore be recognized as the fill of a dammed-lake basin.

Detailed description of depositional facies and their interpretation for these formations revealed the presence of thick (>10 m) delta-front deposits in the distal part of each formation (Dill et al., 2001; Sakai et al., 2001, 2008). Thick delta-front deposits are characterized by foreset beds at ca. $30^{\circ}$ inclination. The foreset beds contain small-scale sediment gravity flow deposits such as grain flows and debris flows as well as thin turbidites and graded very fine sand and silt deposits that are rich in mica flakes and were deposited from suspension fallout. Rare wave-generated sedimentary structures (such as wave-ripple laminations) were observed in the foreset beds: gravitational processes were the major driving force of sediment transport on the delta front. The deltas developed in the northern and eastern basin are therefore recognized as fluvialdominated deltas (cf. Bhattacharya and Walker, 1992; Bhattacharya, 2006). 

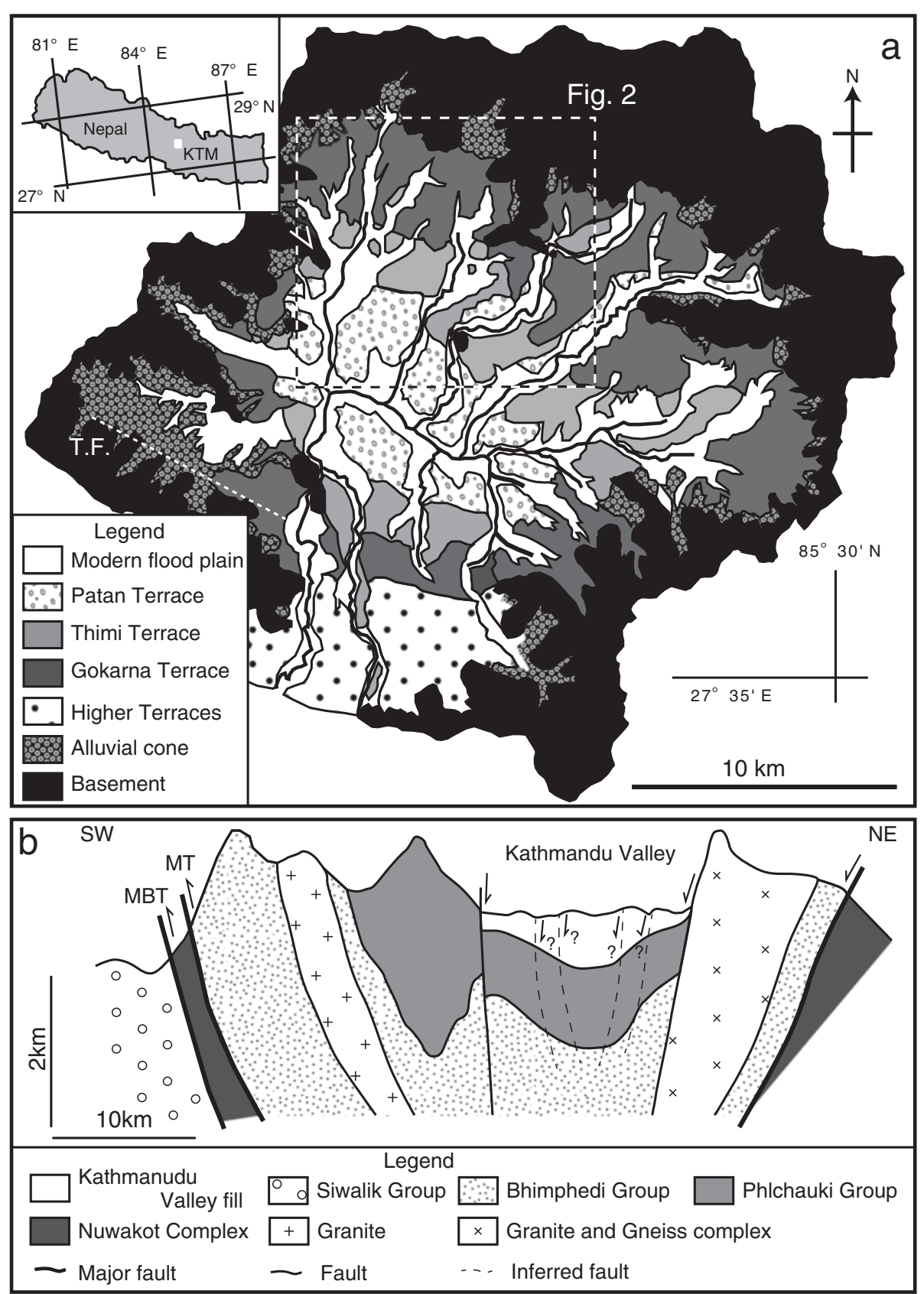

Fig. 1 a Location map of Kathmandu Valley and the topographic classification of the basin. The study area is indicated by the dotted line. T.K. = Thankot Fault. b Schematic geologic cross-section around the Kathmandu Valley (modified from Sakai et al.(2002)). MBT = Main Boundary Thrust, MT= Mahabharat Thrust (Main Central Thrust)

\section{Tectonics of the basin}

The NW-SE lineations are clear from the distribution of the basement rocks within the basin as well as the outcrops of the basement rock on the margin of the basin (Fig. 2). Moribayashi and Maruo (1980) reported a gap in the depth of the basement rock across some lineations beneath the Pleistocene sediments, indicating that some of these lineations are or used to be active faults. From geomorphological analyses, the Thankot Fault (Asahi,
2003), which contains the Chandragiri Fault (Saijo et al., 1995), in the southwestern part of the basin has been recognized as an active reverse fault (Fig. 1). However, this fault is recognized to contribute to the uplift of the Chandragiri Range, and its contribution to the basin subsidence appears to have been small or almost negligible (cf. Asahi, 2003). The specific mechanisms for the Quaternary subsidence are still unclear. Some of the lineations could be active faults and are attributed to 


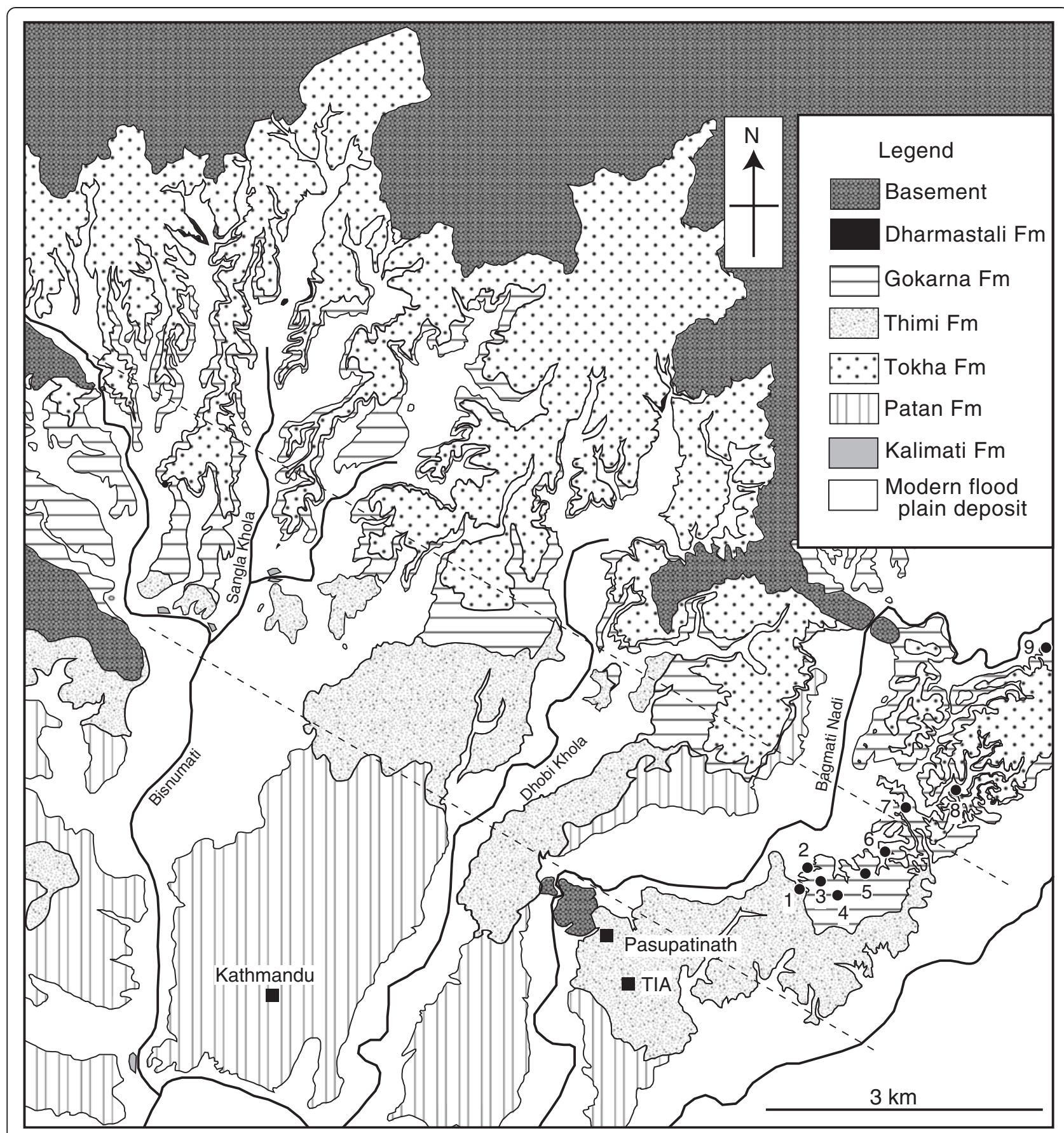

Fig. 2 Geologic map of the study area. The dashed lines indicate the approximate positions of lineations. Numbers are locations of columnar sections in Fig. 3. TIA = Tribhuvan International Airport

subsidence of the basin. Sakai and Gajurel (2012) identified a buried flexure around Mulpani (between Locs. 6 and 7 in Fig. 2) and suggested the presence of a fault that is still active or was active until soon after the end of the deposition of the Tokha Formation, because the top of the Gokarna Terrace (i.e., the top of the Tokha Formation) is higher to the east of Mulpani (around Loc.
7 of Fig. 3) than to the west (Fig. 3), indicating the relative subsidence to the west of this lineation.

\section{Method}

A sedimentological survey was performed to reconstruct the spatio-temporal changes in the depositional environment (Fig. 3) in the Mulpani area, where the Gokarna 


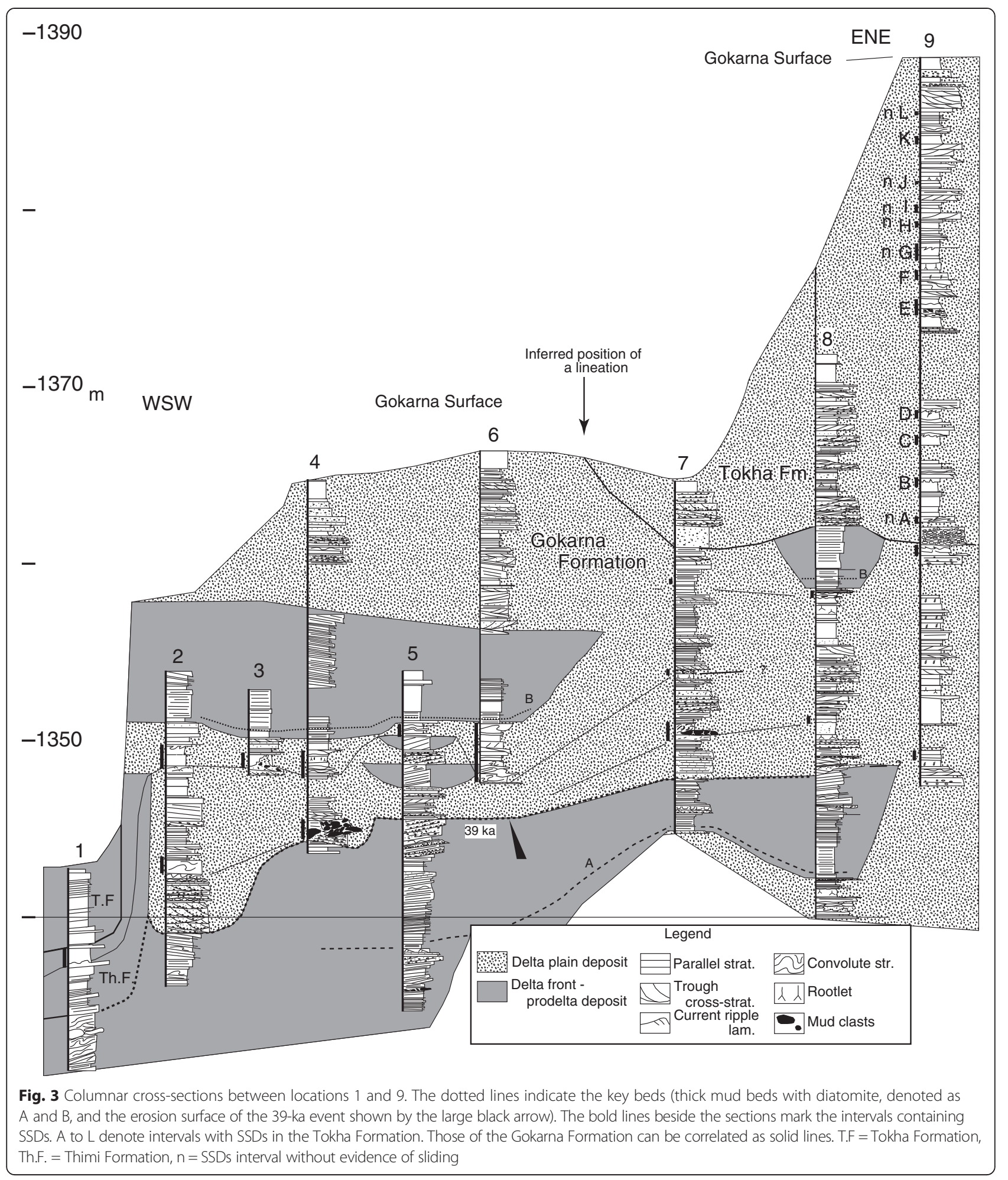

and Tokha formations are widely exposed. Beds with SSDs were described at all exposures around Mulpani. The SSDs at Loc. 9 in the stratigraphic cross-sections (Fig. 3) were the main focus of the survey for the following reasons: (1) fluvial channel fill deposits, which could indicate the removal of sediments recording the evidence of earthquakes are less frequent than in other Tokha Formation localities, suggesting a higher possibility of 
discovery of seismic records in the sedimentary succession, (2) exposures are excellent and fresh due to active sand and silt mining, and (3) a nearly complete succession of the Tokha Formation can be observed at this site. The sediments of Loc. 9-1, which is located $300 \mathrm{~m} \mathrm{NW}$ of Loc. 9, were also described to show the lateral extent of the beds with SSDs. The recurrence period was calculated from the number of discovered seismite, by which the duration of the Tokha Formation (20 to $17 \mathrm{ka}$ in calibrated ${ }^{14} \mathrm{C}$ ages: Sakai et al. (2008)) was divided.

\section{Results}

\section{SSD structures in the Tokha formation}

The application of facies analysis for the Locs. 9 and 9-1 sediments resulted that all the sediments of this site were deposited on a delta plain environment (fluvial channel, marsh and shallow pond). A fluvial channel fill deposit (up to $1.5 \mathrm{~m}$ thick) consists of parallel stratified and trough cross-stratified gravelly sand. A marsh deposit (up to $2 \mathrm{~m}$ thick) is characterized by block-colored, rooted sandy silt or silt. Massive silt (up to $0.5 \mathrm{~m}$ ) is interpreted as having been of a pond origin. At least twelve intervals with SSDs (interval A to L in Figs. 4, 5) were discovered. Four examples at Locs. 9 and 9-1 are described below.

\section{Example 1 (Interval D at Loc. 9: Fig. 6)}

The interval containing deformed sediment is $0.6 \mathrm{~m}$ thick. The interval consists of three parts: basal massive sand (up to $5 \mathrm{~cm}$ thick), gray silt, and overlying blackcolored poorly sorted sandy silt. The boundary of the massive sand and the overlying silt is undulating. A small mud clast ("mc" in Fig. 6a) at the base of the overlying silt penetrates into the massive sand without disturbance of the lower boundary of the sand. The silt can be divided into three portions (lower, middle and upper portions). The lower portion of the silt (ca. $0.1 \mathrm{~m})$ contains small lenses and balls of fine to very fine sand and is convoluted (Fig. 6b). A strongly stretched, thin, sandy silt layer marks the top of the lower portion. The middle portion appears to be massive and contains small sand and mud clasts (Fig. 6a). The sand and mud clsats have rounded shape with diameters up to $2 \mathrm{~cm}$. Some of the sand and mud clasts in this portion are flattened or stretched (sc in Fig. 6a). The boundary between the middle and upper portions is unclear and is represented by a gradual change in color and grain size to become finer upward. There are many small cracks and wedges (of dm-scale depth: cf. Montenat et al., 2007, p.12) filled with black silt in the top of the silt. Some of the cracks and wedges were subjected to deformation after their formation (Fig. 6a). The black sandy silt of the upper part contains small rounded mud clasts and covers the irregular top of the silt unit.

\section{Example 2 (Interval E at Loc. 9: Fig. 7)}

This deformed interval (ca. $0.75 \mathrm{~m}$ thick) consists of basal massive sand and overlying silt (Fig. 7a). The massive sand has an irregular base and top. Minor injection into the underlying silt is also recognized (Fig. $7 \mathrm{~b}$ ). The silt is divided into a lower coarse silt portion and an upper fine silt portion. The base of the silt shows the flame-like features stretching downward (referred to as "anti-flame structures" herein) (Fig. 7b). This structure appears to be fills of small cracks developed in the top of the sand altered to become flame-like by deformation of the walls of cracks and wedges. The top of the massive sand is ripped up into the overlying coarse silt (Fig. 7b).

The lower portion of the silt is massive except for the stretched thin sand layer (less than $1 \mathrm{~mm}$ ) in the middle and contains sand and mud clasts (Fig. 7a, b). The upper portion of the silt is represented by the basal fine silt, in which there are horizontally stretched silt or sand lenses, the coarse silt containing small mud clasts and a deformed black coarser silt layer (Fig. 7a). There are many oblique and vertical cracks and wedges in the top of the upper silt portion that are filled with black silt. The top of the silt is truncated by the gravelly sand layer of a fluvial channel.

\section{Example 3 (Interval $\mathrm{H}$ at Loc. 9: Fig. 8)}

The characteristics of this deformed bed (ca. $0.6 \mathrm{~m}$ thick) are similar to those described above except for the absence of strongly stretched sand and silt lens. This interval hosts two massive coarse silt parts and an interbedded massive sand part (Fig. 8a). Both of the coarse silt parts have an indistinct basal boundary (Fig. 8a). Numerous small rounded mud clasts are scattered in the upper part of the massive sand and in the overlying upper coarse silt (Fig. 8b). The rounded sand clasts, which seem to have been originated from the underlying sand are contained in the upper coarse silt (Fig. 8b). The boundary of the massive sand and the upper coarse silt shows flame-like shape in some part (Fig. 8b), revealing both the parts were under the liquefied state when this boundary deformation occurred. The mud clasts in the massive sand are, therefore, interpreted to have been originated from the overlying massive coarse silt. The top of the upper coarse silt is then overlain by the fine silt and its boundary is undulated. There are minor cracks in the fine silt (Fig. 8c).

The graded and laminated silt containing small organic fragments, which cannot be seen in normal marsh deposits represented by black-colored, rootled sandy silt or silt, covers the deformed interval (Fig. 8a, c). The plant fragments and small mud clasts are aligned parallel to the bedding plain in this silt part. This part may have been formed by suspension fallout in stagnated water with high silt concentration associated with earthquake tremor, 


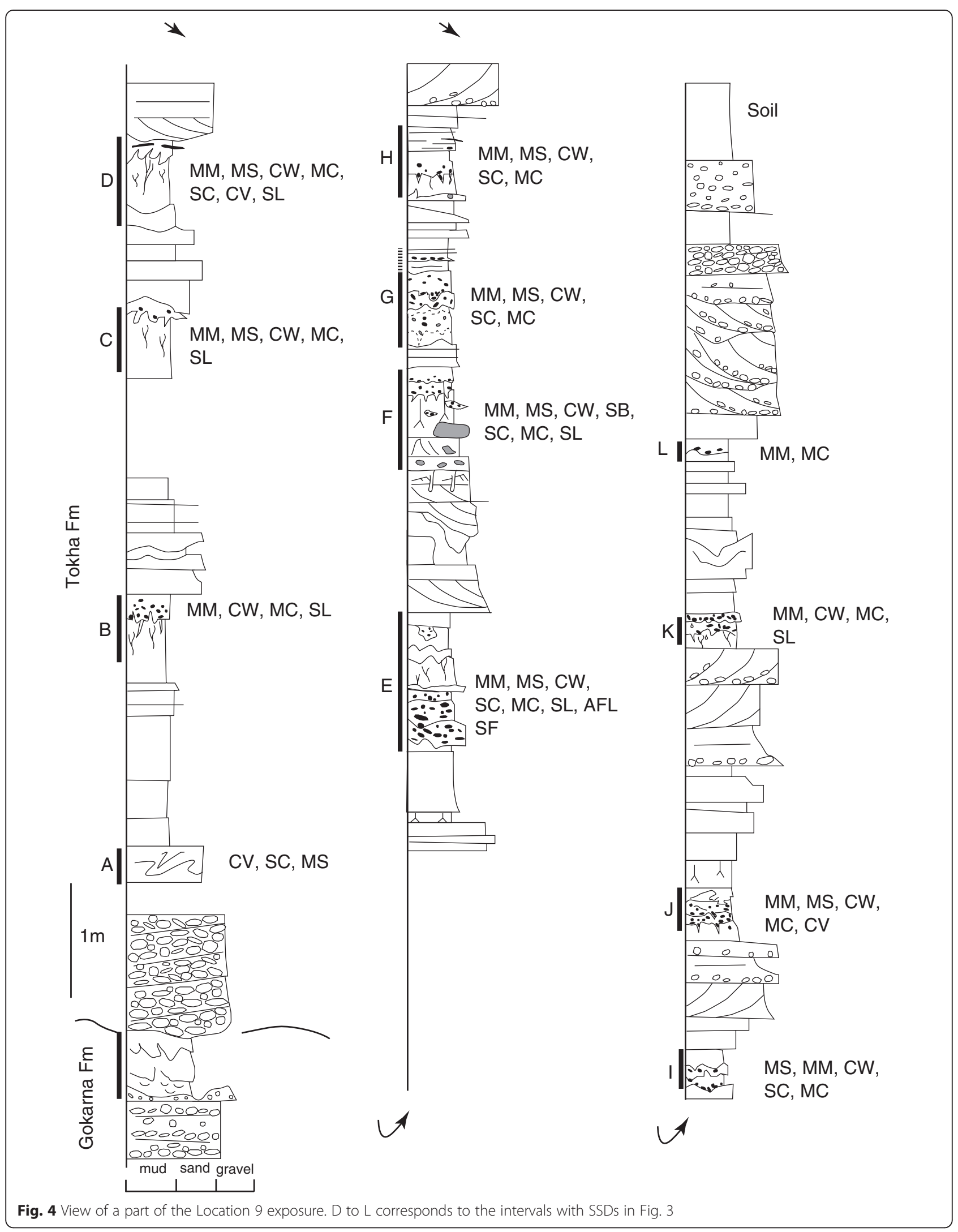




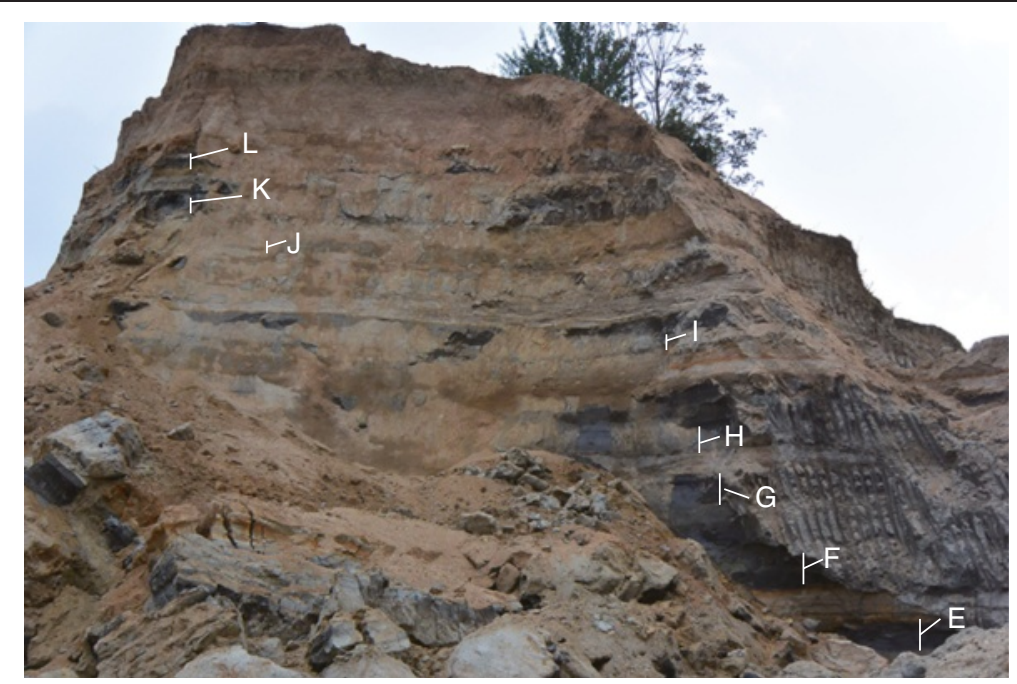

Fig. 5 Columnar cross section of the Location 9. Abbreviations indicate type of deformation structures in each bed. CW =cracks and wedges, $\mathrm{AFL}=$ antiflame structure, $\mathrm{SC}=$ sand clasts, $\mathrm{SB}=$ sand ball, $\mathrm{MC}=$ mud casts, $\mathrm{MS}=$ massive sand, $\mathrm{MM}=$ massive silt, $\mathrm{SL}=$ sand and silt lens, $\mathrm{SF}=$ slip face, $\mathrm{CV}=$ convolute structures, $\mathrm{GF}=$ graded fault

which caused resuspension of less cohesive silt in a small pond.

\section{Example 4 (Interval C at Loc. 9-1: Fig. 9)}

The fault-grading structure described firstly in Seilacher (1969) was discovered in silt of the interval C (0.1 m thick) at Loc. 9-1 (Fig. 9a). The characteristics of the faultgrading structure here is similar to those in Seilacher (1969, 1984); the lower fault-graded (FG) part, in which fault displacement becomes smaller downward with gradational contact with the undeformed sublayer, the rubbled part (RP), in which breccia of the FG part silt are mixed with silty matrix, and the upper homogenized part (HP), consisting of massive silt with scattered small fragments of the FG part silt (Fig. 9b).

\section{Correlation of intervals with SSDs between Locs. 9 and 9-1}

The intervals with SSDs described at Loc. 9 were correlated with those at Loc. 9-1 (Fig. 10). The top of these two sections, which correspond to the top of the Gokarna Terrace, was horizontally correlated (Fig. 10). The exposure containing the interval $\mathrm{E}$ at Loc. 9-1 is wide enough to allow direct visual correlation of this interval between two exposures. The basal part of the interval E at Loc. 9-1 is inclined and is represented by massive silty sand, truncating the underlying parallel and trough cross-stratified gravel beds (Figs. 10, 11). This inclination is the result of sliding when deformation occurred as suggested by the presence of slip face in the basal part of the interval. The deformed interval, associated with the sliding, is then truncated by the overlying fluvial channel fill deposit (Fig. 11).
There are minor gaps in level of the intervals $F, G$ and $\mathrm{K}(\mathrm{ca} .0 .5-0.7 \mathrm{~m})$ between these two locations. But such gaps can be explained by minor topographic relieves on the delta plain between the locations. The interval $\mathrm{H}$ may be missing at Loc. 9-1 because of erosion by fluvial channels (Fig. 10). The intervals A, B, H and I could not be correlated because of the absence of the exposure at Loc. 9-1. These four intervals continue well within the exposure of Loc. 9. (e.g. Fig. 5). It is speculated that they could be correlatable with SSDs intervals in other exposures.

There is a thin SSDs interval (ca. $0.2 \mathrm{~m}$ thick) between the intervals $J$ and $\mathrm{K}$ in the Loc. 9-1 succession. Because it was not found in other locations around Loc. 9 and 9-1, this interval was excluded from the calculation of the earthquake recurrence period.

\section{Discussion}

\section{Origin of SSDs}

Many studies have tried to deny nonseismic processes for the creation of SSDs such as slumps and rapid sedimentation to explain the SSDs formation (cf. Gajurel et al., 1998; Martín-Chiviet et al. 2011; Mugnier et al., 2011), because there are no distinct single criterion to identify seismites (cf. Jones and Omoto, 2000; Montenat et al., 2007; Fortuin and Dabrio, 2008; Wallace and Eyles, 2015). Wide extent of SSDs horizons is also one of important factors for seismite identification.

Major deformation structures discovered here were (1) massive sand, (2) massive coarse silt with numerous mud and sand clasts, (3) stretched sand and silt lenses, (4) fine silt with cracks and wedges and (5) convolute structure. 


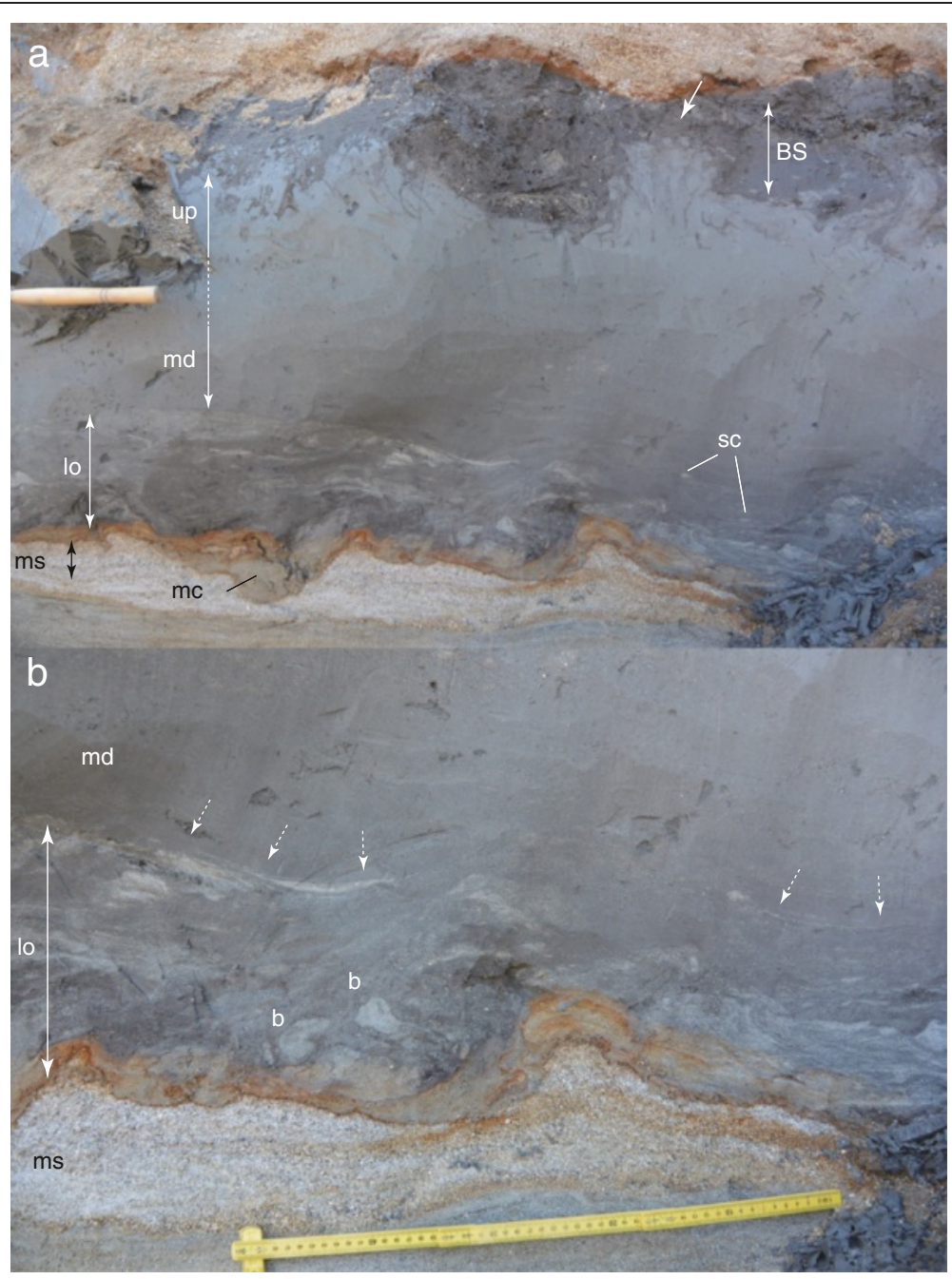

Fig. 6 Outcrop photographs of the SSDs of Example 1. a View of the entire SSDs interval. The solid arrow near the top of the silt indicates the cracked top. The scale is $0.3 \mathrm{~m}$ long. $\mathrm{mc}=$ mud clasts, $\mathrm{sc}=$ sand clasts, $\mathrm{ms}=$ massive sand, lo = lower portion, $\mathrm{md}=$ middle portion, up = upper portion, $\mathrm{BS}=$ black sandy silt. $\mathbf{b}$ Close-up photograph of the basal part of the interval. Note the strongly sheared and stretched thin sand layer (dotted arrows), suggesting a fluidization of the overlying silt interval. $b=$ sand ball. The scale is $0.5 \mathrm{~m}$ long

These structures as well as other minor structures imply that liquefaction, fluidization and brittle and ductile deformation occurred when SSDs were generated.

These are lines of strong evidence for liquefaction of the massive sand. The penetration of mud clasts in the massive sand of Example 1 from above without deformation of base of the sand, and the injection of sand into the underlying silt in Example 2, indicate the liquefaction of these sand. The ordinary massive sand associated with liquefaction due to strong tremor shows upward injections in many cases. In this case, the strong compressional stress exerted in the overlying silt interval due to sliding (discussed below) may have retarded the upward injection of liquefied sand or evidence of the upward injection may have been erased by the sliding to be convoluted portion (the lower portion of the silt part in the Example 1) or to be horizontally stretched as thin sand layers (Examples 1 and 2).

The coarse massive silt with sand and mud clasts is similar to the homogenized bed of Seilacher (1984), the intraclast breccia layer of Agnon et al. (2006) and mud breccia unit of Sakaguchi et al. (2011), which were interpreted as having been attributed to seismic ground motion, having caused Kelvin-Helmholtz instability between soft sediment layers (cf. Heifetz et al., 2005). The coarse silt described in the Examples $1-3$ is different from those previously described in the following points: (a) the sand and mud clasts are rounded in this case: those in the previous description are angular in shape. Some of them are stretched to be sand and silt lenses, and (b) the massive coarse silt with sand and mud clasts is graded upward into the fine silt with cracks and 


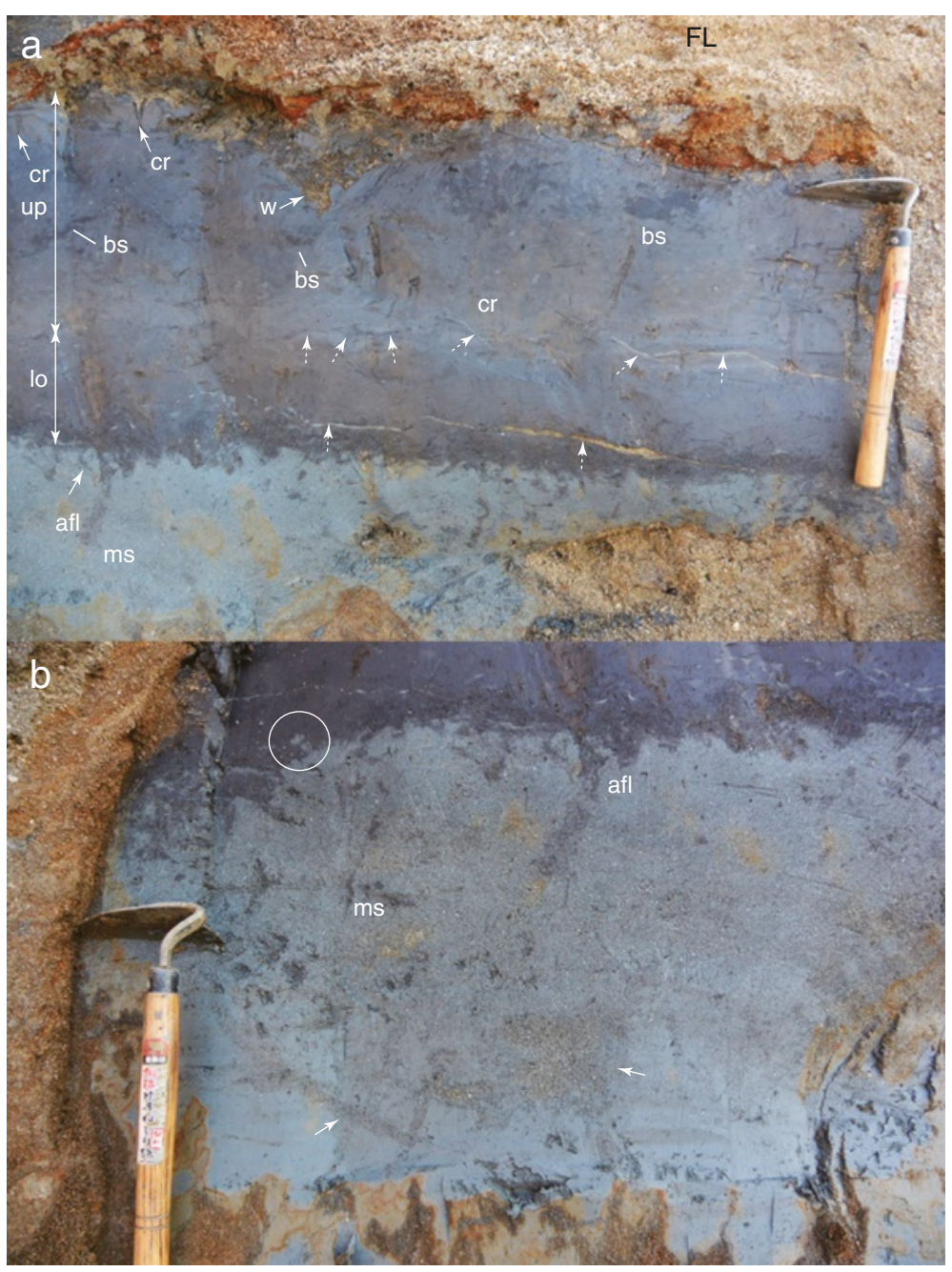

Fig. 7 Outcrop photographs of the SSDs of Example 2. a The major part of the SSDs interval. The arrowed intervals in the silt indicate the lower (lo) and upper (up) portions. Note that black sandy silt layer(bs) which shows undulation in geometry of the layer in the upper part, suggestive of ductile deformation. The stretched sandy slit layers are suggested by dotted arrows, indicating a minor sliding of the bed. The trowel is $0.35 \mathrm{~m}$ long. $\mathrm{ms}=$ massive sand, afl = anti-flame structure, $\mathrm{cr}=\mathrm{cracks}, \mathrm{w}=$ wedge, $\mathrm{FL}=$ Fluvial channel fill deposit. $\mathbf{b}$ Close-up photograph of the massive sand bed below the muddy interval. The arrow indicates a minor injection of sand into the underlying silt, suggesting the liquefaction of sand.

The circled part shows ripped-up sand clasts from the sublayer

wedges: the previously described SSDs layers are then covered with undeformed sediments deposited after deformation (cf. Seilacher, 1984; Agnon et al. 2006; Sakaguchi et al., 2011). Therefore the Kelvin-Helmholtz instability model cannot be simply applied for this case.

The generation of coarse silt with sand and mud clasts may have been explained by brecciation of slightly less dense but cohesive silt and sand and mixing of the brecciated clasts (sand and mud clasts) with less cohesive silt (silt slurry) created by seismic tremor. The rounded sand and mud clasts and the stretched sand and silt within the coarse silt portion imply that they were moved and sheared within silt slurry; fluidization occurred below the fine silt.

The overlying fine silt contains cracks and wedges filled with black mud derived from above. These can be recognized as open cracks and wedges. Some cracks and wedges were observed in a sandy interval (Fig. 4). Montenat et al. (2007) summarized the characteristics of thixotropic wedges that are developed in coarse-grained layers and are similar to the cracks and wedges in this case. Such wedges are attributed to the limited and periodical occurrence of liquefaction and subsequent sediment collapse (Montenat et al., 2007). However, Montenat et al. (2007) suggested that the cracks and wedges should be discriminated from those of cryogenic origin in order to specify the seismic origin. In this case, the Kathmandu Valley was located in subtropical and temperate climate zones and the presence of ice wedges is not realistic (cf. Gayer et al. 2006).

There was no agent causing strong tensional stress to create cracks and wedges as well as liquefaction of sand, 


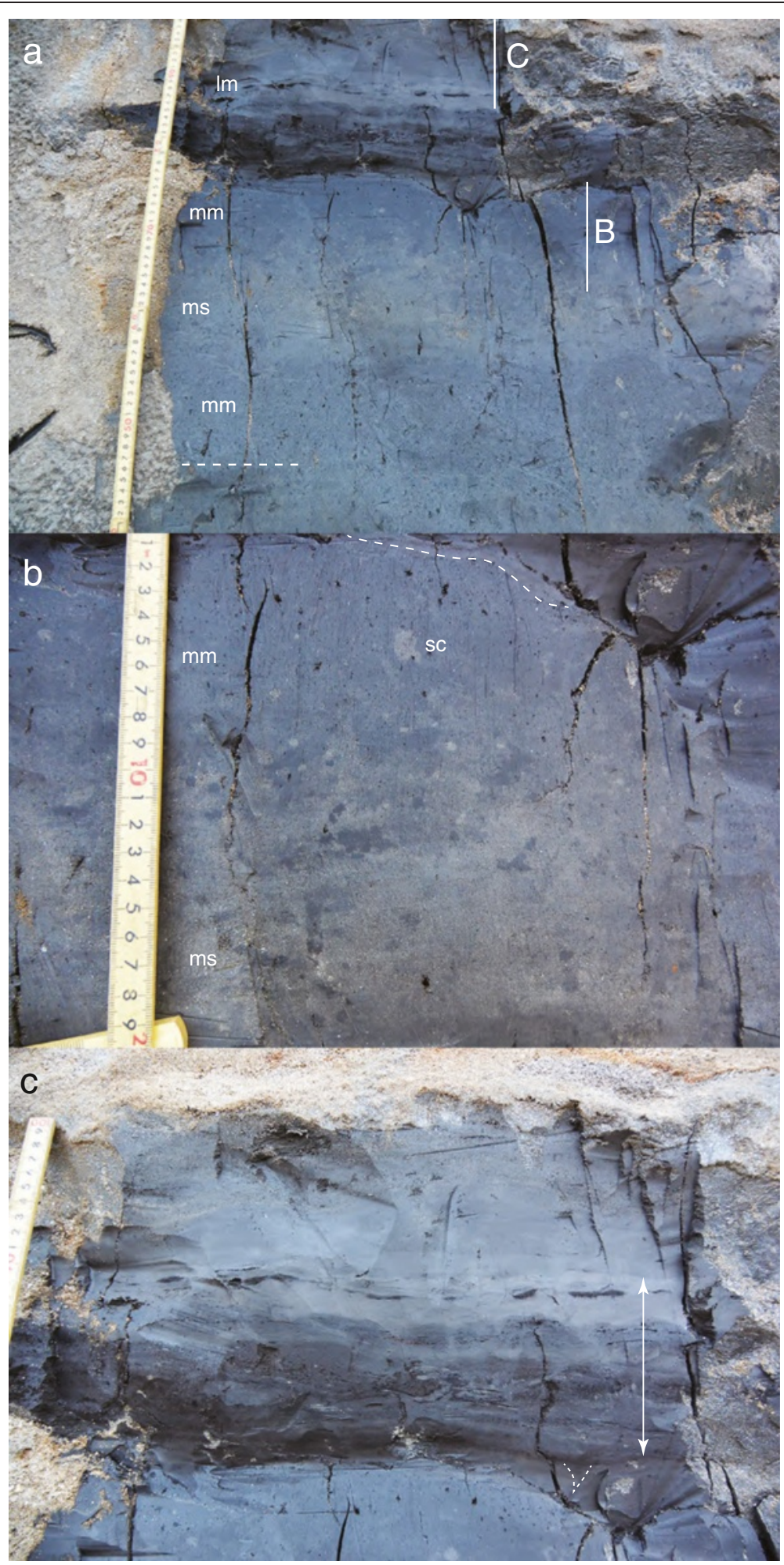

Fig. 8 Outcrop photographs of the SSDs of Example 3. a The whole view of the SSDs interval. The dotted white line indicates the approximate position of the base of the SSDs interval. $\mathbf{b}$ and $\mathbf{c}$ are the horizon of Figs. $8 \mathrm{~b}$ and $\mathrm{c}$. Im = laminated silt. $\mathbf{b}$ The close-up photograph of the interval. Note the mud clasts in the massive sand supplied from above and sand clasts in the coarse silt originated from the underlying sand. The dotted line indicates the top of the coarse silt. c The close-up photograph of the graded and laminated silt (arrowed part). The dotted line indicates a small crack 


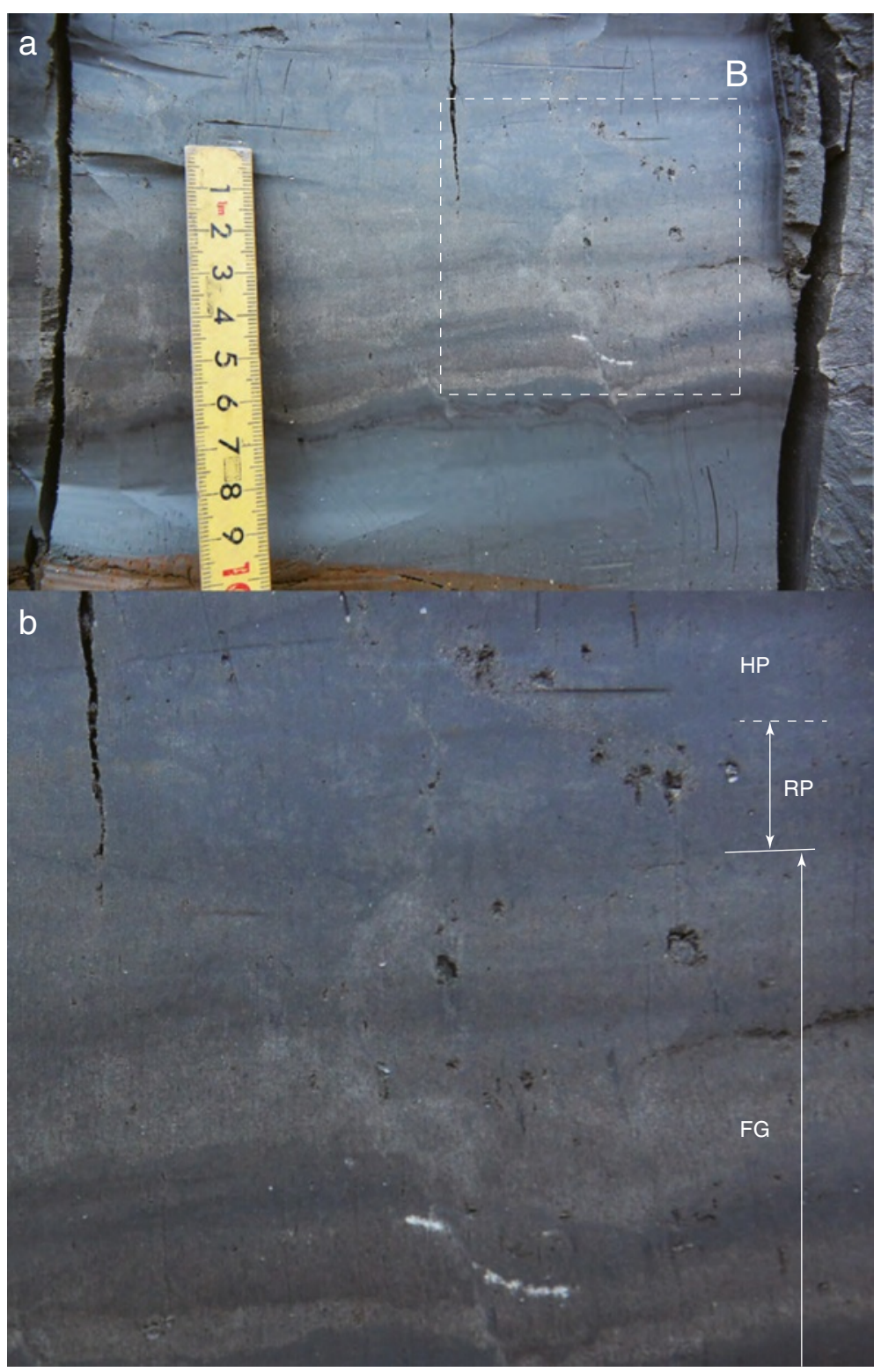

Fig. 9 SSDs photograph of Example 4. a The graded fault. b Close-up photograph of the SSDs interval. FG = fault grading zone, RP = rubbled part, $\mathrm{HP}=$ homogenized part

fluidization of unconsolidated silt other than earthquake tremors, because the sediments above and below the SSD intervals consist of fluvial stream or marsh deposits, which are characteristic of almost flat environments. The setting of a fluvial-dominated delta system allows us to exclude the effects of large waves (storms) from consideration. The correlation of SSDs intervals between Locs. 9 and 9-1 revealed that many of them were correlated between locations. Those which were not found at Loc. 9-1 because of outcrop loss and erosion by fluvial channel, also have exposure-wide continuation of intervals. All the SSDs here can, therefore, be recognized as seismites (see discussions in Mugnier et al. (2011)).
In the silty SSDs reported in previous studies, the brittle deformation predominates in the lower part of the SSDs interval, and ductile or fluidization (homogenization) in the upper part due to deformation of less cohesive silty sediments (Seilacher 1969, 1984). Only Example 4 from the interval $\mathrm{C}$ shows deformation similar to those reported in previous studies (e.g. Seilacher, 1969, 1984; Agnon et al. 2006) (Figs. 9, 12a). On the contrary, almost all other intervals, including the interval $\mathrm{C}$ at Loc. 9, shows deformation different from the ordinary pattern mentioned above: fluidization in the lower coarse silt and brittle deformation in the upper fine silt (Fig. 12b). Some of examples like Example 3 have alternation the 


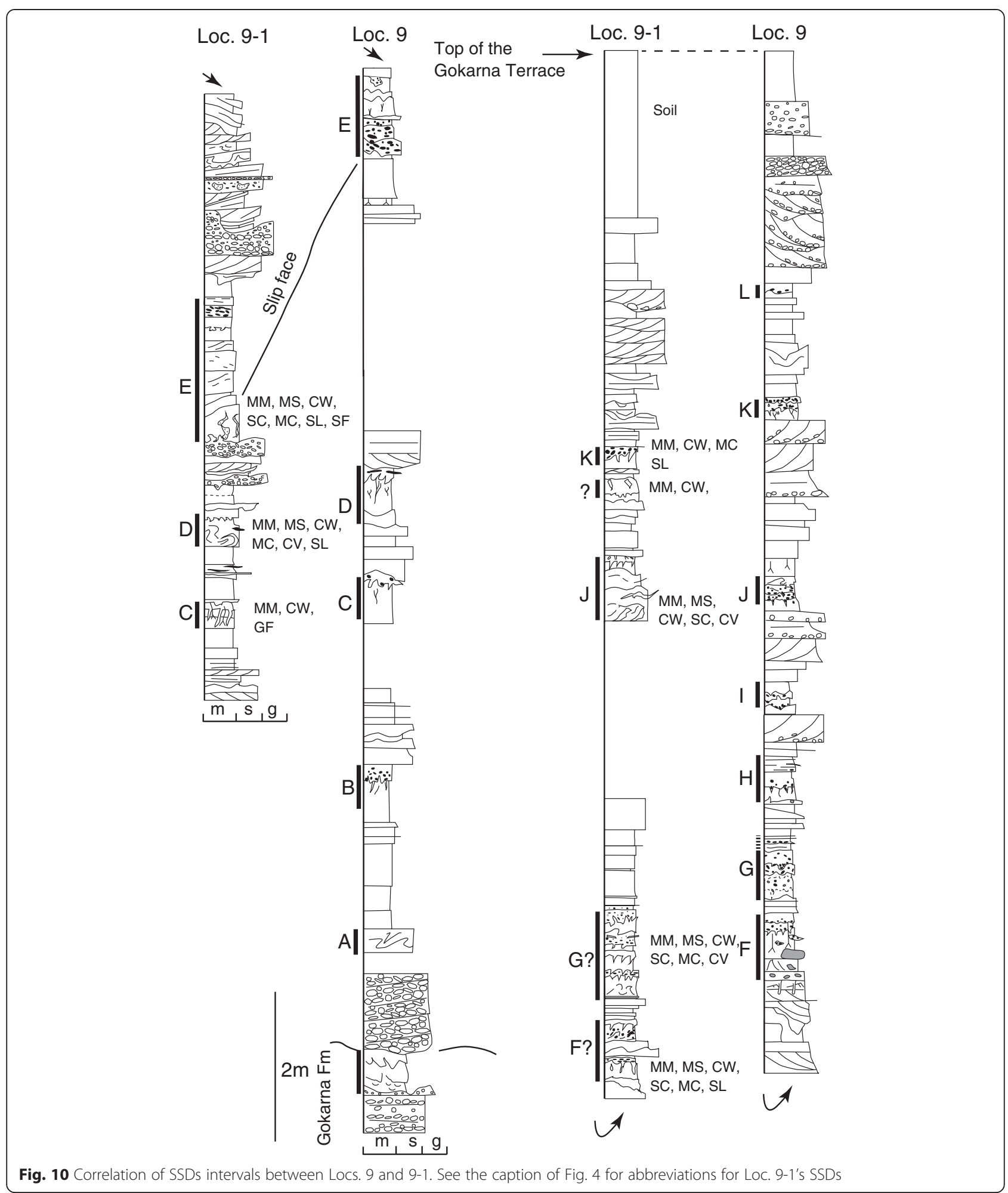

fluidized part and brittle-deformation part (Figs. 8, 12b). Evidence of ductile deformation was also observed in the transition from the coarse to fine silt as in Example 2. These facts obviously suggest that the upper brittly-deformed fine silt was compacted more than the fluidized lower coarse silt before they were deformed. This peculiar consolidation pattern may be explained by seasonal lake-level changes: near surface sediments may have experienced consolidation due to drying of the surface during the dry season. Sakai et al. (2001) 


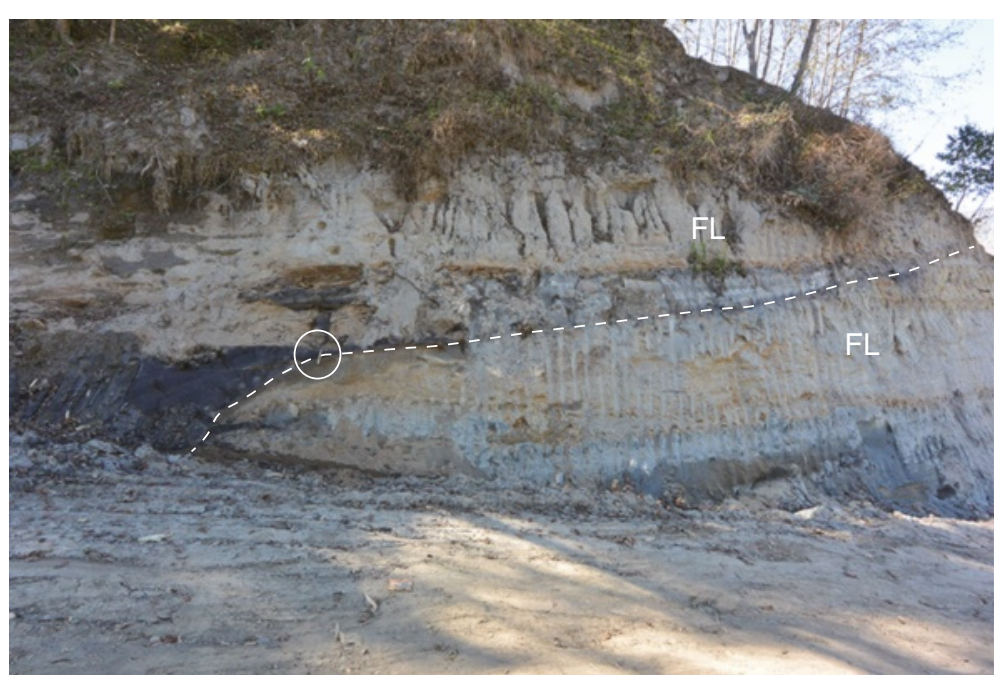

Fig. 11 Outcrop photograph of Interval E at Loc. 9-1. The scale (circled) is $0.35 \mathrm{~m}$ long. The dotted line indicates the horizon of the slip face. $\mathrm{FL}=$ Fluvial channel fill deposit

discovered evidence of high-frequency lake-level changes due possibly to annual wet and dry condition from the previous Gokarna (containing Tokha Formation) and Thimi formations.

The fluidized coarse silt with sheared sand and silt layers may have been responsible for minor sliding of the SSDs horizons, which introduced shear stress within the liquefied layer below the surface. In particular, the interval E obviously shows sliding of the beds. The Locs. 9 and 9-1 are close to the buried flexure (Fig. 3), which was active during the Pleistocene (Sakai and Gajurel, 2012) and its activity could be the trigger of slidings. Tilting of the surface was the only possible trigger for sliding, because the environment of sedimentation was almost flat. This result suggests that sliding of the plain area could happen in conjunction with future large earthquakes centered around the Kathmandu Valley. As the future studies, the distribution of seismites hosting evidence of sliding within the valley should be specified for creation of the hazard map indicating the possibility of sliding as well as for the risk management of the plain area.

\section{Scale of earthquakes}

Seismites in location 9 are mostly $0.4-0.8 \mathrm{~m}$ in thickness except for the uppermost one, which is $0.2 \mathrm{~m}$ thick. Some parts of beds must have been lost due to sliding (as suggested by the presence of fragmented mud); thus, the initial seismite thickness may have been greater than presently observed. If we simply apply the empirical relationship between the intensity of tremors and seismite thickness (Hibsch et al., 1997) as applied by Gajurel et al. (1998), most of the seismites may have been formed by events stronger than $\mathrm{X}$ on the MMI scale.
However, large deformation structures associated with the expulsion of a sediment-water mixture, suggesting large-scale liquefaction, have been documented in other cases (e.g. Montenat et al., 2007; Fortuin and Dabrio, 2008; Rossetti et al. 2011; Santos et al., 2012), and such large structures were not observed in these examples. Most previously described seismites are associated with sand and coarse silt, but the major sediment type of these examples is fine and coarse silt, which shows deformation sturctures different from the previously described examples. Therefore, the intensity of tremors for the seismites described here should be carefully discussed on the basis of additional information such as their lateral extent.

\section{The recurrence period of large earthquakes during the Tokha phase}

For the estimation of the recurrence period of earthquakes based on the sediment records, the chronological control is crucial for obtaining the more reliable value (e.g. Agnon et al. 2006). The ages of the lower and upper limits of the main body of the Tokha Formation (20 ka and $17 \mathrm{ka}$ ) are used for the recurrence period estimation and are suitable for its estimation due to the following reasons: (1) the lower limit, dated as $20 \mathrm{ka}$ (17 $\mathrm{ka}$ in the uncalibrated age) was obtained from a well-preserved single pine cone collected from the base of the main body of the Tokha Formation (i.e. the age was obtained from the analysis of the ideal sample) and (2) the upper limit of the formation is also constrained by the oldest ${ }^{14} \mathrm{C}$ age of the Patan Formation (17 ka: Sakai et al. 2008). Absence of unconformities and paleosols in this formation, suggestive of a continuous lake-level rise and sediment accumulation in the Tokha phase, is another 


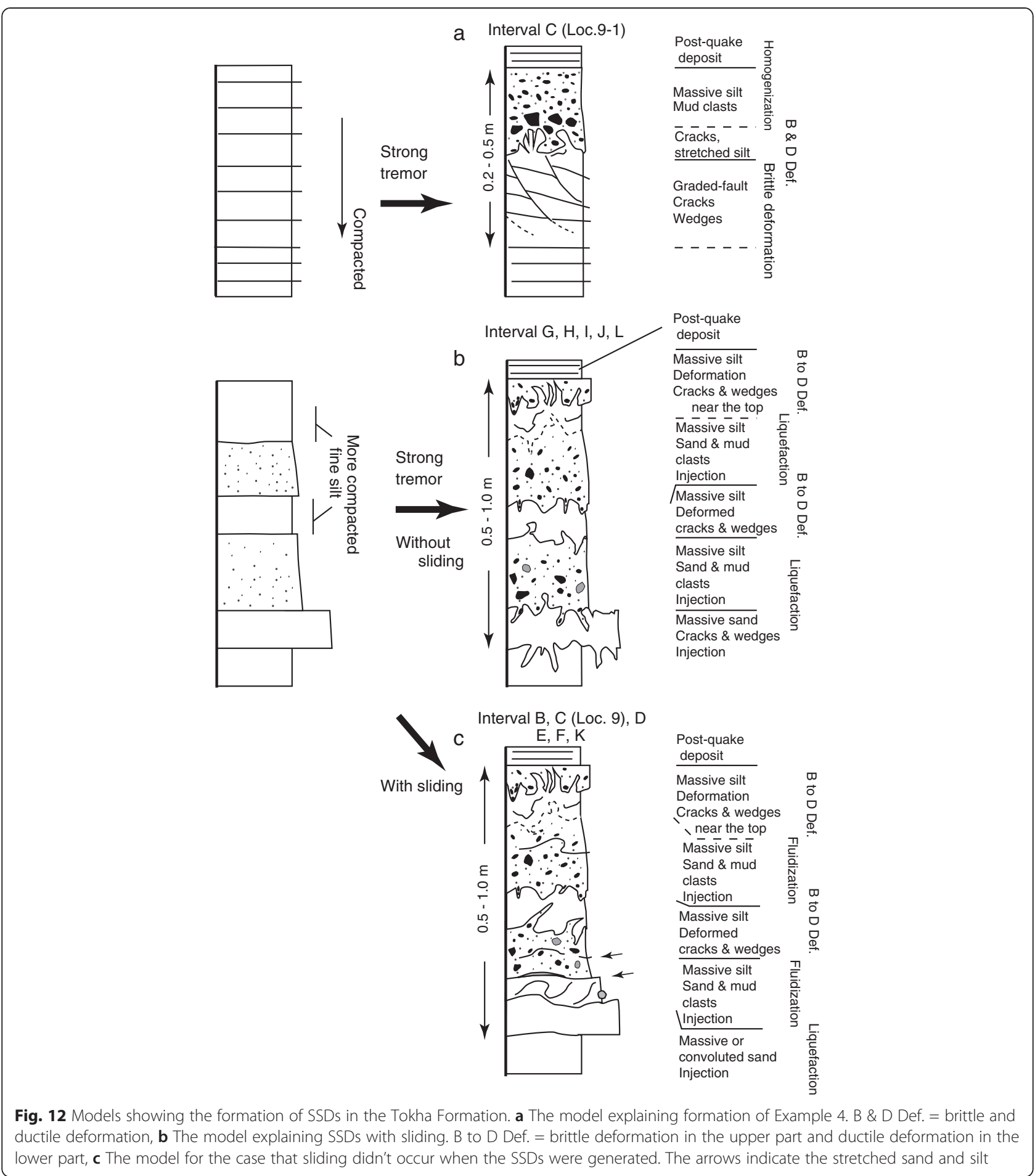

suitable condition for the recurrence period estimation from this formation. The thickness of sediments between two seismites in the studied sections is almost constant (Fig. 5), implying the nearly-constant time intervals between two large earthquakes.
In this study, at least twelve seismites were identified from the Tokha Formation. Dividing the time period of the Tokha Formation by the number of seismites provides a simple estimate of the recurrence period of earthquakes, which is about $0.25 \mathrm{ka}$. Because some part 
of the section is missing due to outcrop loss, the presence of other seismites is expected in the missing interval as the case of SSDs interval between J and K at Loc. 9-1 which was ignored in this paper: thus, the period of large-earthquakes may be shorter than this value.

Mugnier et al. (2011) compiled historical earthquake records and showed that strong earthquakes with an MMI value larger than $\mathrm{X}$ occurred three times in the last 800 years. The time interval between the two major earthquakes of AD 1408 and 1934 is approximately $0.52 \mathrm{ka}$, but the time interval between the AD 1255 and AD 1408 events is about $0.15 \mathrm{ka}$. The average time interval of these earthquake events is $0.34 \mathrm{ka}$, which is close to the recurrence period obtained in this study. The value obtained in this study, $0.25 \mathrm{ka}$, for earthquakes that have intensity and magnitude strong enough to cause surface ruptures and sediment deformation in the muddy sediments of the basin seems to be appropriate, although additional detection of seismites is required to obtain a more reliable value for the recurrence period.

\section{Conclusions}

The seismic recurrence time has been estimated from the Pleistocene succession of the Kathmandu Valley. The estimated earthquake recurrence time based on interbedded seismites in the Tokha Formation is about $0.25 \mathrm{ka}$, which is almost equal to the average time intervals of the last three major earthquakes. The estimated recurrence time must be confirmed by future geologic studies in the Kathmandu Valley. Our study also revealed possibility of sliding of the plain area by minor tilting of the basin in conjunction with future large earthquakes. This phenomenon should be considered in the future risk management in Kathmandu Valley.

\section{Competing interests}

The authors declare that they have no competing interests.

\section{Authors' contributions}

TS, APG and HT collected data from field. TS and APG created figures and draft. All authors read and approved the final manuscript.

\section{Acknowledgements}

The study was partly supported by Grand in aid from the MEXT, Japanese Government to TS (no. 23540533). The authors thank Dr. R.K. Dahal for providing an opportunity for publishing this study in the journal. The manuscript was largely improved based on comments by two anonymous reviewers.

\section{Author details}

'Department of Geoscience, Shimane University, Matsue 690-8504, Japan. ${ }^{2}$ Department of Geology, Tribhuvan University, Ghantaghar, Kathmandu, Nepal. ${ }^{3}$ Institute for Applied Satoyama Research, Ogaki 503-1624, Japan.

Received: 8 April 2015 Accepted: 14 October 2015

Published online: 14 November 2015

\section{References}

Agnon A, Migowski C, Marco S (2006) Intraclast breccias in laminated sequences reviewed: Recorders of paleo-earthquakes. In: Enzel Y, Agnon A, Stein M (eds)
New frontiers in Dead Sea paleoenvironmental research, vol 401, Geol Soc Am Spec Paper., pp 195-214

Ambraseys NN, Douglas I (2004) Magnitude calibration of north Indian earthquakes. Geophys J Int 158:1-42

Asahi K (2003) Thankot active fault in the Kathmandu Valley, Nepal Himalaya. J Nepal Geol Soc 28:1-8

Bhattacharya JP (2006) Deltas. In: Posamentier HW, Walker RG (eds) SEPM Special Publications No. 84, Tulsa., pp 237-292

Bhattacharya JP, Walker RG (1992) Deltas. In: Walker RG, James NP (eds) Facies Models - response to sea level changes. Geological Association of Canada, Ontario, pp 157-177

Dill HG, Kharel BD, Singh VK, Piya B, Busch K, Geyh M (2001) Sedimentology and paleogeographic evolution of the intermontane Kathmandu basin, Nepal, during the Pliocene and Quaternary. Implications for formation of deposits of economic interest. J Asian Ear Sci 19:777-804

Fortuin AR, Dabrio CJ (2008) Evidence for Late Messinian seismites, Nijar Basin, south-east Spain. Sedimentology 55:1595-1622

Gajurel AP, Huyghe P, France-Lanord C, Mugnier UL, Upreti BN, Le Fort P (1998) Seismites in the Kathmandu basin, Nepal. J Nepal Geol Soc 18:25-134

Gajurel AP (2006) Etude sédimentologique et géochimique (isotopes stables) des bassins synorogéniques de l'Himalaya du Népal (Siwaliks et bassin de Kathmandu), PhD thesis, Université Joseph Fourier

Gajurel AP (2011) Sedimentary facies at southern marginal part: an indicator of depositional environmental fluctuation in Kathmandu basin, Nepal. J Nepal Geol Soc 43:333-351

Gayer E, Lavé J, Pik R, France-Lonard C (2006) Monsoon forcing of Holocene glacier fluctuations in Ganesh Himal (Central Nepal) constrained by cosmogenic ${ }^{3} \mathrm{He}$ exposure ages of garnets. Earth Planet Sci Lett 252:275-288

Heifetz E, Agnon A, Marco S (2005) Soft sediment deformation by Kelvin-Helmholtz Instability: a case from Dead Sea earthquake. Earth Planet Sci Lett 236:497-504

Hibsch C, Alvarado A, Yepes H, Perez VH, Sebrier M (1997) Holocene liquefaction and soft sediment deformation in Quito (Ecuador): a paleoseismic history recorded in lacustrine sediments. J Geodynamics 24:259-280

Ikehara K (2000) Large earthquakes recorded as deep-sea turbidites in the Rishir Trough, Northernmost Hokkaido. Quat Res (Daiyonki Kenkyu) 39:569-574, Japanese with English Abstract

Jones AP, Omoto K (2000) Towards establishing criteria for identifying trigger mechanisms for soft-sediment deformation: a case study of Late Pleistocene lacustrine sands and clays, Pnikobe and Nakayamadaira Basins, northeastern Japan. Sedimentology 47:1211-1226

Kasten KA (1984) Earthquakes as a triggering mechanism for debris flows and turbidites on the Calabrian Ridge. Mar Geol 55:13-33

Malik JN, Mathew G (2005) Evidence of paleoearthquakes from trench investigations across Pinjore Garden fault in Pinjore Dun, NW Himalaya. J Earth Sys Sci 114:387-400

Malik JN, Sahoo AK, Shah AA, Shinde DP, Jayal N, Singhvi AK (2010) Paleoseismic evidence from trench investigation along Hajipur fault, Himalayan Frontal Thrust, NW Himalaya: Implications of faulting pattern on landscape evolution and seismic hazard. J Str Geol 32:350-361

Martín-Chiviet J, Palma RM, López-Gómez J, Kietzmann DA (2011) Earthquakeinduced soft-sediment deformation structures in Upper Jurassic open-marine microbialites (Neuquén Basin, Argentina). Sed Geol 235:210-221

Montenat C, Barrier P, d'Estevou PO, Hibsch C (2007) Seismites: an attempt at critical analysis and classification. Sed Geol 196:5-30

Moribayashi S, Maruo Y (1980) Basement topography of the Kathmandu Valley, Nepal: an application of gravitational method to the survey of a tectonic basin in the Himalayas. J Japan Soc Engineer Geol 21:80-87

Mugnier JL, Huyghe P, Gajurel AP, Upreti BN, Jouanne F (2011) Seismites in the Katumandu basin and seismic hazard in central Himalaya. Tectonophys 509:33-49

Nakata T (1989) Active faults of the Himalaya of India and Nepal. Geol Soc Am Special Paper 232:243-264

Natori H, Takizawa F, Motojima K, Nagata S (1980) Natural gas in the Kathmandu Valley. Chisitsu News 312:24-35 (in Japanese)

Rossetti DF, Bezerra FHR, Goés AM, Neves BBB (2011) Sediment deformation in Miocene and post-Miocene strata, Northeastern Brazil: evidence for paleoseismicity in a passive margin. Sed Geol 235:172-187

Saijo K, Kimura K (2007) Expansion of an ancient lake in the Kathmandu basin of Nepal during the Late Pleistocene evidenced by lacustrine sediment underlying piedmont slope. Him J Sci 4:41-48 
Saijo K, Kimura K, Dongol G, Komatsubara T, Yagi H (1995) Active faults in South western Kathmandu basin, Central Nepal. J Nepal Geol Soc $11: 217-224$

Sakaguchi A, Kimura G, Strasser M, Screaton EJ, Curewitz D, Murayama M (2011) Episodic seafloor mud brecciation due to great subduction zone earthquakes. Geology 39:919-922

Sakai H (2001) Stratigraphic division and sedimentary facies of the Kathmandu Basin Group, central Nepal. J Nepal Geol Soc 25:19-32

Sakai T, Gajurel AP (2012) Excursion Guide for northern and eastern Kathmandu Valley. In: Sakai H, Sakai T, Gajurel AP, Fujii R (eds) Guidebook for excursion on Geology of Kathmandu Valley. Special Publication of Nepal Geological Society, vol 2. Nepal Geological Society, Kathmandu, pp 21-41

Sakai H, Fujii R, Kuwahara Y (2002) Changes in depositoinal systems of the Paleo-Kathmandu Lake caused by uplift of the Nepal Lesser Himalayas. J Asian Earth Sci 20:267-276

Sakai T, Gajurel AP, Tabata H, Upreti BN (2001) Small amplitude lake level fluctuations recorded in aggrading deltaic deposits of the lower parts of the Upper Pleistocene Thimi and Gokarna formations, Kathmandu Valley, Nepal. J Nepal Geol Soc 25:43-51

Sakai T, Gajurel AP, Takagawa T, Tabata H, Ooi N, Upreti BN (2006) Discovery of sediment indicating rapid lake-level fall in the late Pleistocene Gokarna Formation, Kathmandu Valley, Nepal: implication for lake terrace formation. Quat Res (Daiyonki Kenkyu) 25:99-112

Sakai T, Gajurel AP, Tabata H, Ooi N, Takagawa T, Kitagawa H, Upreti BN (2008) Revision of lithostratigraphy of fluvio-lacustrine sediments comprising in the northern Kathmandu basin in central Nepal. J Nepal Geol Soc 37:25-44

Santos MGM, Almeida RP, Mountney NP, Fragoso-Cesar ARS (2012) Seismites as a tool in the palaeoenvironmental reconstruction of fluvial deposits: the Cambrian Guarda Velha Formation, southern Brazil. Sed Geol 277-278:52-60

Seilacher A (1969) Fault-graded beds interpreted as seismites. Sedimentology 13:155-159

Seilacher A (1984) Sedimentary structures tentatively attributed to seismic events. Mar Geol 55:1-12

Shrestha OM, Koirala A, Karmacharya SL, Pradhananga UB, Pradhan R, Karmacharya R (1998) Engineering and environmental geological map of the Kathmandu Valley (1:50,000). Department of Mines and Geology, His Majesty's Government of Nepal

Simms MJ (2007) Uniquely extensive soft-sediment deformation in the Rhaetian of the UK: evidence for earthquake or impact? Palaeogr Palaeocl Palaeoecol 244:407-423

Sims JD (1973) Earthquake-induced structures in sediments of Van Norman Lake, San Fernando, California. Science 182:161-163

Sims JD (1975) Determining earthquake recurrence time intervals from deformational structures in young lacustrine sediments. Tectonophys 29:141-156

Stöcklin J, Bhattarai KD (1977) Geology of the Kathmandu Area and central Mahabharat Range, Nepal. Nepal Department of Mines and Geology, Himalayan Report, 86

Tamrakar NK, Shrestha P, Maharjan S (2009) Facies association and depositional environment of fan-delta sequence in southwest Kathmandu Basin, Nepal. Bull Dept Geol Tribhuvan Univ 12:1-16

Wallace K, Eyles N (2015) Seismites within Ordovician-Silurian carbonates and clastics of Southern Ontario, Canada and implications for intraplate seismicity. Sed Geol 316:80-95

Wesnousky SG, Kumar S, Mohindra R, Thakur VC (1999) Uplift and convergence along the Himalayan Frontal Thrust of India. Tectonics 187:967-976

Yoshida M, Igarashi Y (1984) Neogene to Quaternary lacustrine sediments in the Kathmandu Valley, Nepal. J Nepal Geol Soc 4:73-100

\section{Submit your manuscript to a SpringerOpen ${ }^{\odot}$ journal and benefit from:}

- Convenient online submission

- Rigorous peer review

- Immediate publication on acceptance

- Open access: articles freely available online

- High visibility within the field

- Retaining the copyright to your article

Submit your next manuscript at $>$ springeropen.com 